\title{
Megaporosity and Permeability of Thalassinoides-Dominated Ichnofabrics in the Cretaceous Karst-Carbonate Edwards- Trinity Aquifer System, Texas
}

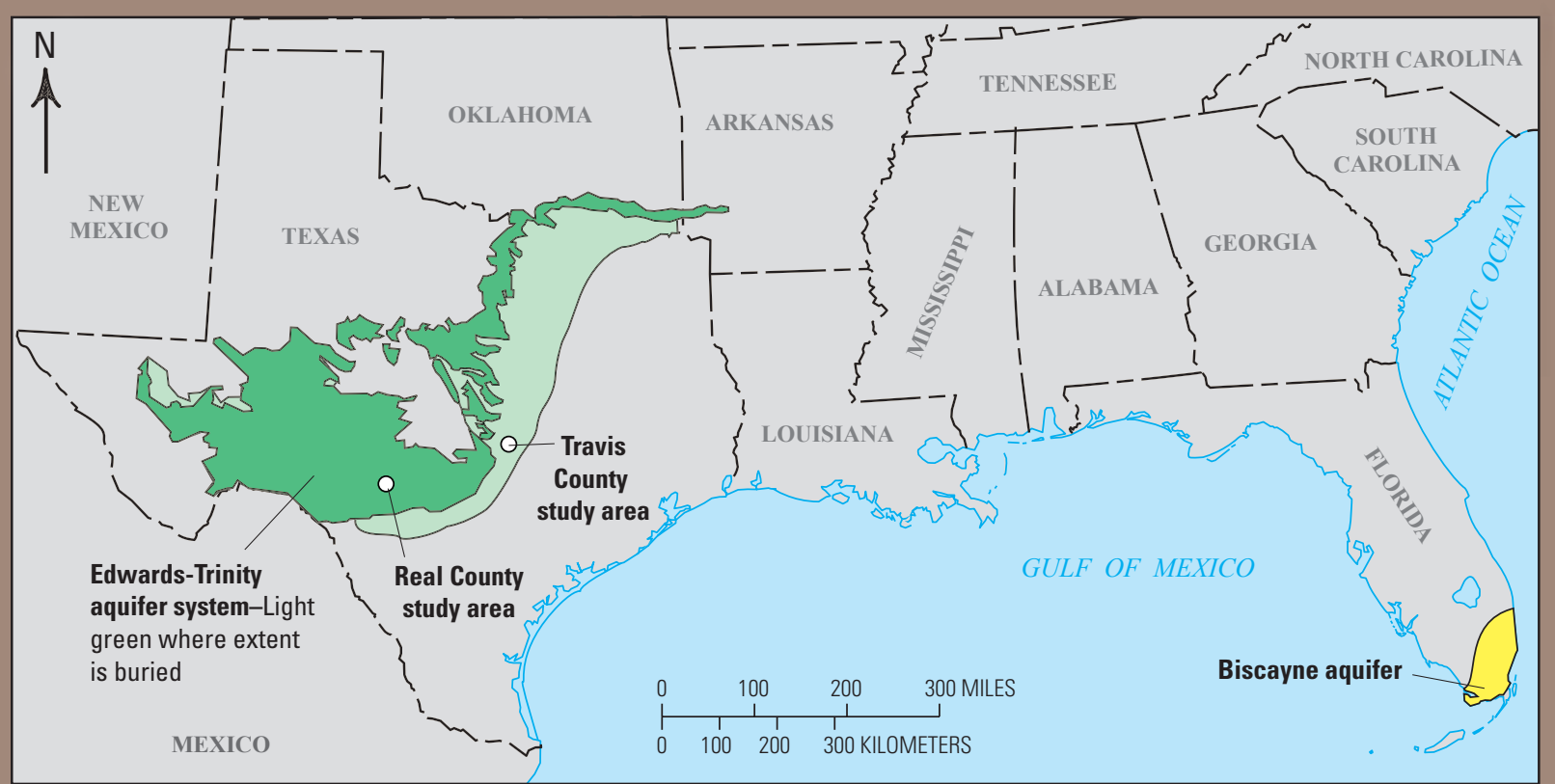

Figure 1. Map showing two case study areas in central Texas. Modified from Cunningham and others (in press).

Current research has demonstrated that trace fossils and their related ichnofabrics can have a critical impact on the fluidflow properties of hydrocarbon reservoirs and groundwater aquifers. Most petroleum-associated research has used ichnofabrics to support the definition of depositional environments and reservoir quality, and has concentrated on siliciclastic reservoir characterization and, to a lesser degree, carbonate reservoir characterization (for example, Gerard and Bromley, 2008; Knaust, 2009). The use of ichnology in aquifer characterization has almost entirely been overlooked by the hydrologic community because the dynamic reservoir-characterization approach has not caught on with hydrologists and so hydrology is lagging behind reservoir engineering in this area (de Marsily and others, 2005). The objective of this research is to show that (1) ichnofabric analysis can offer a productive methodology for purposes of carbonate aquifer characterization, and (2) a clear relation can exist between ichnofabrics and groundwater flow in carbonate aquifers.

\section{Case Studies in Real and Travis Counties, Central Texas}

Research at two study areas in Real and Travis Counties, central Texas (fig. 1), demonstrates a relation between ichnofabrics, megaporosity (Choquette and Pray, 1970), and permeability where Thalassinoides-dominated ichnofabrics occur within the unsaturated part of the karst-carbonate Edwards-Trinity aquifer system (figs. 2 and 3). The research centers on the influence of thalassinidean or thalassinid-like crustacean-produced ichnofabrics (Goldring and others, 2007) on carbonate aquifer characteristics. Results show evidence of concentrated paleogroundwater flow through stratiform, touching-vug, megapororous flow zones linked to secondary fabric-selective intraburrow and interburrow megaporosity within Thalassinoides-dominated ichnofabrics. At both sites (fig.1), megaporous bioturbation is within Cretaceous carbonate strata representative of a restricted shallow-marine, platform-interior 


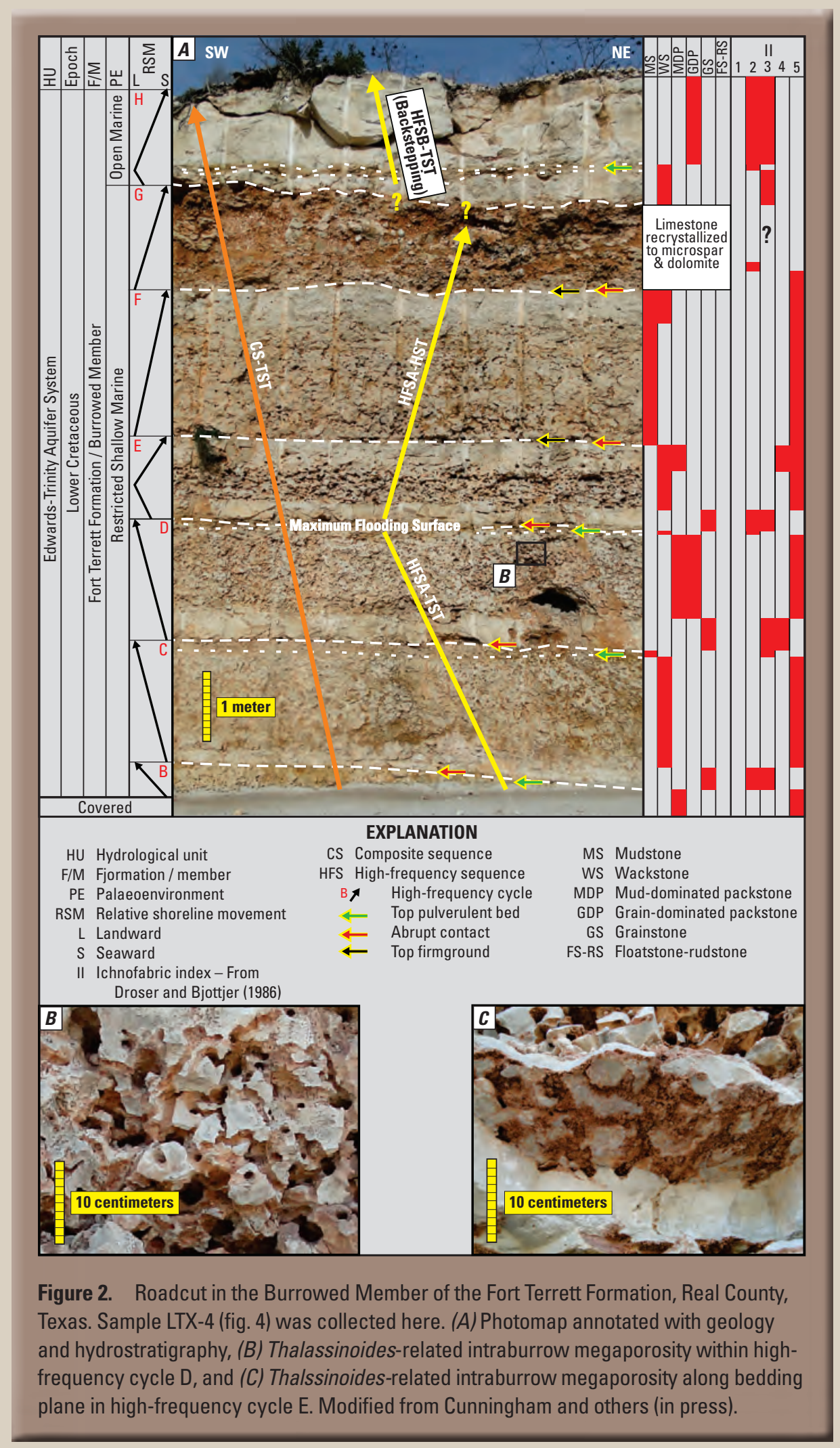

paleoenvironment. Lattice Boltzmann calculated intrinsic permeabilities for intraburrow and interburrow megaporosity, represented in whole-core-scale computer renderings made from X-ray computed tomography scans, are $5.6 \times 10^{6}$ and $1.8 \times 10^{6}$ Darcies, respectively (fig. 4). The Cretaceous megaporous, maximum Thalassinoides ichnofabrics have similar intrinsic permeability values as compared to intraburrow and interburrow megaporosity related to Ophiomorpha-dominated ichnofabrics in Pleistocene shallow-marine platform carbonates of the Biscayne aquifer in southern Florida (Cunningham and others, 2009; Cunningham and Sukop, 2011) (figs. 1 and 2). Highly permeable Thalassinoides-dominated ichnofabrics, where present, could play an important role in groundwater movement in saturated parts of the Edwards-Trinity aquifer system as suggested by Barker and Ardis (1996), and thus, improve the water supply for urban and agricultural areas. 


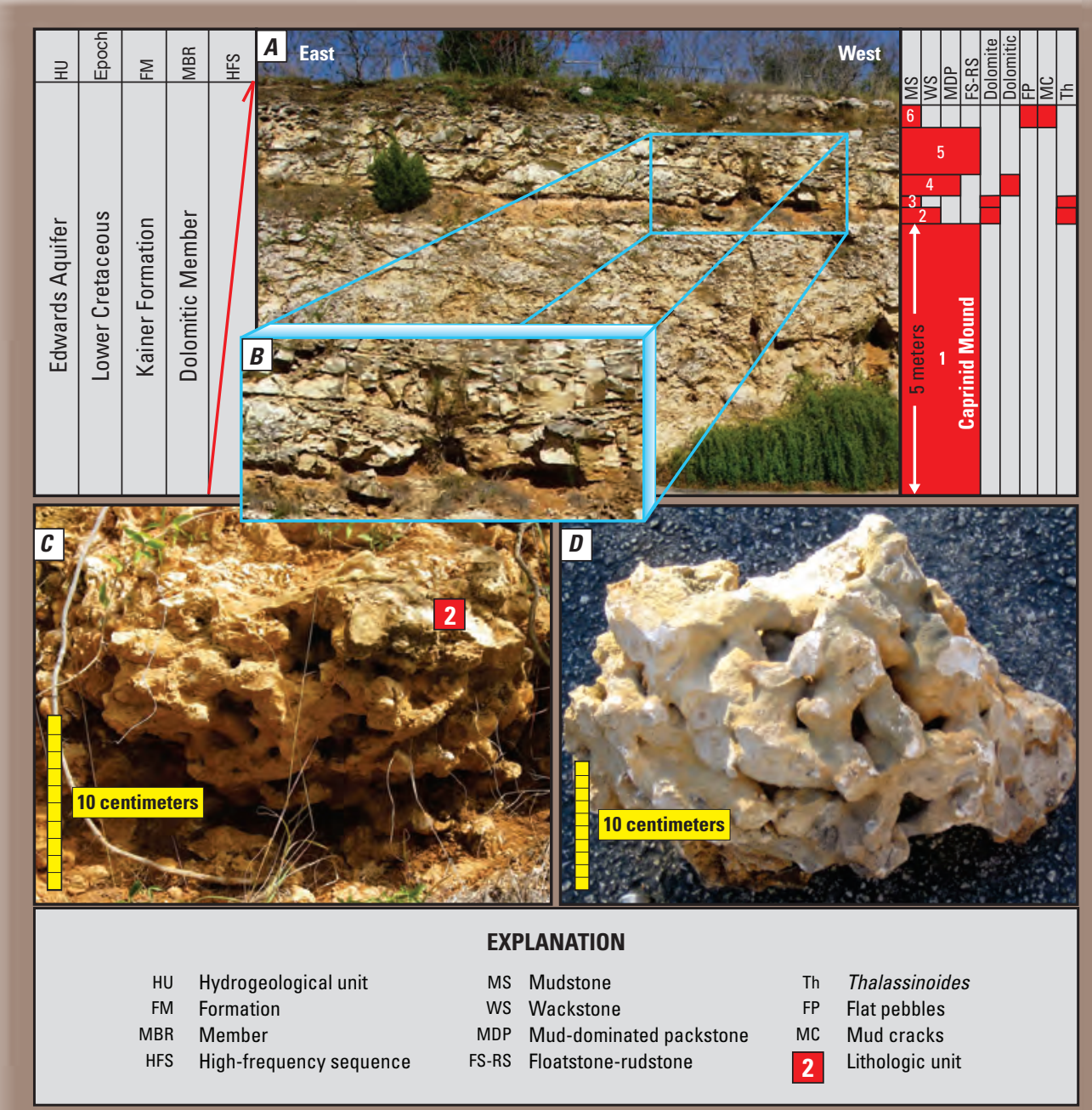

Figure 3. Kainer Formation, Travis County, Texas. (A) Hydrostratigraphy, lithostratigraphy, and carbonate textures of an abandoned quarry wall. (B) close-up of inset (blue rectangle) showing beds that have collapsed into stratiform megaporosity related to a Thalassinoidesdominated ichnofabric developed in unit 2, (C) Thalassinoides tunnel casts near the base of unit 2, and (D) sample (TXEA-1) of Thalassinoides casts and interburrow megaporosity from unit 2 (fig. 4). Modified from Cunningham and others (in press).

In the Cretaceous examples, fabric-selective dissolution in and around carbonate ichnofabrics related to Thalassinoidesdominated Cruziana ichnofacies are shown to have a marked impact on karst development of (1) highly permeable stratiform megaporosity; (2) caves, which commonly conform to upper and lower stratal boundaries in high-frequency cycles; and (3) solution collapse structures. The stratiform networks of extremely permeable megaporosity can be mapped and, as such, represented in groundwater flow and transport computer simulations. Comparative analyses between Cretaceous and Pleistocene carbonate aquifers emphasize that the past (Mesozoic) can be the key to the Pleistocene. The two studies provide corroborating illustrations of the impact that ichnofabrics can have on groundwater flow in shallow-marine, carbonate platform aquifers. These analogues offer excellent examples for refining conceptualization of groundwater flow in the Pleistocene carbonates of the Biscayne aquifer for use in assessing and predicting change associated with implementation of restoration plans for the Greater Everglades in southern Florida.

\section{Acknowledgments}

The U.S. Geological Survey Priority Ecosystems Science Program provided major funding for comparisons of the Biscayne aquifer and Edward-Trinity aquifer system. Bill Ward (deceased), Rene Barker (Texas State University), Nico Hauwert (Austin Watershed Protection Department), Scott Hiers (Austin Watershed Protection Department), and Al Broun (Hays Trinity Groundwater Conservation District) provided insight into Texas geology. X-ray CT scans were conducted at HighResolution X-Ray CT Facility at the University of Texas.

\section{References Cited}

Barker, R.A., and Ardis, A.F. 1996, Hydrogeologic framework of the Edwards-Trinity aquifer system, west-central Texas: U.S. Geological Survey Professional Paper 1421-B, 61 p.

Choquette, P.W., and Pray, L.C., 1970, Geologic nomenclature and classification of porosity in sedimentary carbonates: American Association of Petroleum Geologists Bulletin, v. 54, p. 207-250. 


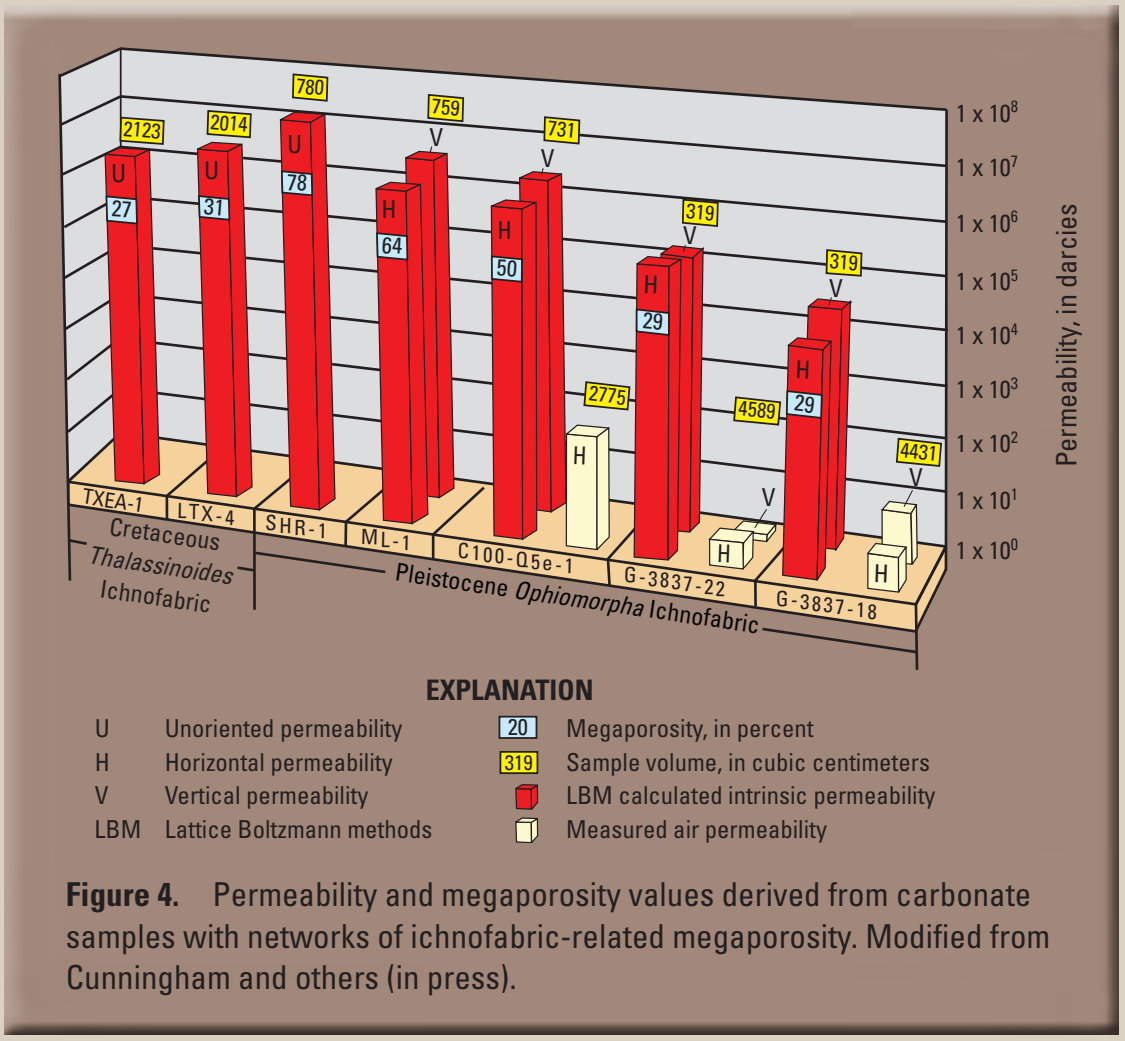

Cunningham, K.J., and Sukop, M.C., 2011, Multiple technologies applied to characterization of porosity and permeability of the Biscayne aquifer, Florida: U.S. Geological Survey Open-File Report 2011-1037, 8 p.

Cunningham, K.J., Sukop, M.C., and Curran, H.A., (in press), Carbonate aquifers; in Knaust, D. and Bromley, R.G., (eds.), Trace Fossils as Indicators of Sedimentary Environments: Amsterdam, Elsevier.

Cunningham, K.J., Sukop, M.C., Huang, H., Alvarez, P.F., Curran, H.A., Renken, R.A., and Dixon, J.F., 2009, Prominence of ichnologically influenced macroporosity in the karst Biscayne aquifer: Stratiform "super-K" zones: Geological Society of America Bulletin, v. 121, p. 164-180.

de Marsily, Gh., Delay, F., Gonçalvès, J., Renard, Ph., Teles, V., and Violette, S., 2005, Dealing with spatial heterogeneity:

Hydrogeology Journal, v. 13, p. 161-183.
Droser, M.L., and Bottjer, D.J., 1986, A semiquantitative field classification of ichnofabric: Journal of Sedimentary Petrology, v. 56, p. 558-559.

Gerard, J.R.F., and Bromley, R.G. 2008, Ichnofabrics in clastic sediments: Applications to sedimentological core studies, a practical guide: Ibergraphi, Madrid, $100 \mathrm{p}$.

Goldring, R., Cadée, G.C., and Pollard, J.E., 2007, Climatic control of marine trace fossil distribution; in Miller, W., III (ed.), Trace Fossils: Concepts, Problems, Prospects: Amsterdam, Elsevier, p. 159-171.

Knaust, D., 2009, Ichnology as a tool in carbonate reservoir characterization: A case study from the Permian Triassic Khuff Formation in the Middle East: GeoArabia, v. 14, p. 17-38.

\section{By Kevin J. Cunningham and Michael C. Sukop}

\section{For further information, contact:}

Kevin J. Cunningham

U.S. Geological Survey

7500 S.W. 36th Street

Davie, FL 33314

E-mail:kcunning@usgs.gov
Michael C. Sukop

Department of Earth \& Environment

Florida International University

Miami, FL 33199

E-mail: sukopm@fiu.edu 